\title{
STUDI SEMIOTIKA VIDEO KAMPANYE “AHOK PASTI KALAH”
}

\author{
Rafael Reza Fahlevy, Widyo Nugroho \\ Jurusan Ilmu Komunikasi, Fakultas Ilmu Komunikasi, Universitas Gunadarma \\ Akademi Komunikasi Media Radio TV Jakarta \\ rafaelrezaf@gmail.com
}

\begin{abstract}
ABSTRAK
Penelitian ini bertujuan untuk mengetahui makna yang terkandung dalam video Cameo Project yang berjudul "Ahok Pasti Kalah". Video yang di unggah pada tanggal 9 februari 2017 yang merupakan bentuk kampanye untuk mendukung pasangan Basuki Tjahaja Purnama (Ahok) dan Djarot dalam pemilihan umum calon Gubernur DKI Jakarta periode 2017-2022. Penelitian ini menggunakan pendekata kualitatif dengan analisis semiotika Ferdinand de Saussure. Semiotika Saussure mengemukakan bahwa penanda (signifier) adalah simbol yang terdapat pada semua pesan yang disampaikan dan tanda itu sendiri pasti memiliki makna atau disebut petanda (signifier). Hasil analisis yang ditemukan peneliti antara lain, adanya penggunaan Clickbait pada pemberian judul dengan tujuan menaikan views, serta pesan yang terkandung dalam video Ahok Pasti Kalah yaitu pencitraan positif Ahok sebagai Gubernur yang dibutuhkan oleh masyarakat DKI Jakarta.
\end{abstract}

Kata Kunci: Semiotik, Video, Kampanye.

\section{PENDAHULUAN}

Media menjadi salah satu alat pendongkrak untuk menyampaikan kampanye oleh kaum elite politik. Seperti yang dikatakan oleh Senator Marcado bahwa It is clear that media needs poltician, as needs media. There are inextricably joined togetherin a love-hate relationship (Cangara 2009:128). Setiap warga negara berhak melakukan kegiatan politik, salah satunya adalah melakukan dukungan terhadap kandidat yang maju pada pemilihan umum. Banyak cara untuk melakukan dukungan tersebut yang dikemas secara kreatif. Tidak hanya media seperti televisi dan surat kabar saja yang digunakan kampanye politik, namun pesatnya perkembangan teknologi mengakibatkan perubahan bentuk kampanye kreatif yang berubah menggunakan media Youtube.

Salah satu hasil perkembangan teknologi yang meliputi dunia audio visual saat ini adalah Youtube. Hingga saat ini menurut data statistik YouTube, pengguna YouTube diseluruh dunia telah mencapai satu milyar serta total penayangan setiap video yang diunggah ke situs YouTube telah mencapai satu triliun penayangan (Statistc, YouTube.com). Tidak hanya itu setiap menitnya video yang diunggah ke YouTube senilai 300 jam (Statistic, YouTube.com). Sebanyak enam milyar jam rata-rata video di YouTube telah ditonton dalam satu bulan (Statistic, YouTube.com). Berdasarkan data yang dilansir oleh Digital Marketing Ramblings (2013) rata-rata satu pengguna menghabiskan waktu mengakses situs Google terutama 
YouTube selama 462 menit. Cameo Project sendiri sudah memiliki lebih dari 200 ribu subscriber (per bulan April 2017) dan video-videonya sudah ditonton lebih dari 40 juta kali tayang. Terdapat penelitian tentang Cameo Proejct yang dilakukan oleh Sheila Sulthana Taswin dengan menggunakan analisis Semiotika Barthes, yang dimana pesan yang disampaikan pada video "Takotakmiskumis" berisikan tentang Jokowi yang digambarkan sebagai kandidat yang bijak dan pantas dipilih. Sebaliknya, Fauzi Bowo digambarkan sebagai pemimpin yang korup. Hasil penelitian tersebut dibedah dengan analisis semiotika.

Berdasarkan data yang dilansir oleh Digital Marketing Ramblings (2013) rata-rata satu pengguna menghabiskan waktu mengakses situs Google terutama YouTube selama 462 menit. Cameo Project sendiri sudah memiliki lebih dari 200 ribu subscriber (per bulan April 2017) dan video-videonya sudah ditonton lebih dari 40 juta kali tayang. Semiotika sendiri adalah suatu ilmu atau metode analisis untuk mengkaji tanda. Tanda-tanda adalah perangkat yang dipakai dalam upaya berusaha mencari jalan di kehidupan ini, di tengah-tengah manusia dan bersama dengan manusia. Semiotika, atau dalam istilah Barthes, semiologi pada dasarnya hendak mempelajari bagaimana kemanusiaan (humanity) memaknai hal-hal (things). Memaknai (to signify) dalam hal ini tidak dapat dicampuradukkan dengan mengkomunikasikan (to communicate).

Pada tanggal 9 Februari 2017, Cameo Project mengunggah video yang berjudul "Ahok Pasti Kalah!”. Video tersebut adalah bentuk kampanye untuk mendukung Basuki Tjahaja Purnama dalam pemilihan umum calon gubernur DKI Jakarta periode 2017 - 2022. Dalam video yang berdurasi 3 menit 16 detik itu, Martin berbicara bahwa Ahok yang merupakan calon gubernur Jakarta tahun 2017 bisa saja kalah dalam pemilihan umum tersebut. Penelitian ini berfokus pada tanda-tanda yang tampak pada video baik berupa visual maupun audio, dengan menganalisisnya menggunakan teori semiotika Ferdinand de Saussure.

\section{TINJAUAN PUSTAKA}

Pada dasarnya, analisis semiotika memang merupakan sebuah ikhtiar untuk merasakan sesuatu yang aneh, perlu dipertanyakan lebih lanjut ketika kita membaca teks atau narasi tertentu. (Indiwan Seto Wahyu Wibowo dalam buku Semiotika Komunikasi Aplikasi praktis bagi penelitian dan skripsi komunikasi). Suatu tanda menandakan sesuatu selain dirinya sendiri, dan makna (meaning) ialah hubungan antara suatu objek atau idea dan suatu tanda (Littlejohn, 2009). Konsep dasar ini berhubungan dengan seperangkat teori yang membicarakan tentang simbol, bahasa, wacana, dan bentuk-bentuk non verba, serta teori yang menjelaskan 
bagaimana tanda itu bisa tersusun. Semiotika sebagai suatu model dari ilmu pengetahuan social, memahami dunia sebagai suatu hubungan yang memiliki unit dasar dengan 'tanda'. Ahli semiotika, Umberto Eco menyebut tanda sebagai suatu 'kebohongan' dan dalam Tanda ada suatu yang tersembunyi di baliknya dan bukan merupakan tanda itu sendiri. Semiotika berkaitan erat dengan bidang linguistik, yang untuk sebagian, mempelajari struktur dan makna bahasa yang lebih spesifik. Selain linguistik, semiotika juga mempelajari system-sistem tanda nonlinguistik.

Semiotika merupakan bidang studi tentang tanda dan cara tanda-tanda itu bekerja. Dalam memahami studi tentang makna setidaknya terdapat tiga unsur utama yakni; (1) Tanda, (2) Acuan tanda, dan (3) Pengguna tanda. Tanda merupakan sesuatu yang bersifat fisik, bisa dipersepsi indera kita, tanda mengacu pada sesuatu di luar tanda itu sendiri, dan bergantung pada pengenalan oleh penggunaannya sehingga disebut tanda. Misalnya; dalam sebuah adegan ketika Laras mendorong Ipot dan Doni ke luar rumah dengan wajah yang marah, dalam hal ini tanda ekpresi wajah Laras bermakna kemarahan dan ini diakui seperti itu oleh semua orang. Makna disampaikan dari adegan kepada penonton maka komunikasi pun berlangsung. Menurut Littlejohn dalam bukunya yang berjudul Theories on Human Behaviour, Tanda-tanda (Sign) adalah basis atau dasar dari seluruh komunikasi. Manusia dengan perantaraan tanda-tanda dapat melakukan komunikasi dengan sesamanya dan banyak hal yang bisa dikomunikasikan di dunia ini. Sedangkan menurut Umberto Eco, kajian semiotika sampai sekarang membedakan dua jenis semiotika yakni semiotika komunikasi dan semiotika signifikasi.

Semiotika menurut Berger memiliki dua tokoh, yakni Ferdinand de Saussure (18571913) dan Charles Sander Peirce (1839-1914). Kedua tokoh tersebut mengembangkan ilmu semiotika secara terpisah dan tidak mengenal satu sama lain. Saussure di Eropa dan Peirce di Amerika Serikat. Latar belakang keilmuan adalah linguistik, sedangkan Peirce filsafat. Saussure menyebut ilmu yang dikembangkannya semiologi (semiology).

Ferdinand de Saussure mengemukakan teori semiotika yang dimana membagi menjadi dua bagian (dikotomi) yaitu Penanda (signifier) dan Pertanda (signified). Penanda dilihat sebagai bentuk/wujud fisik dapat dikenal melalui wujud karya arsitektur, sedang pertanda dilihat sebagai makna yang terungkap melalui konsep, fungsi dan/atau nilai-nlai yang terkandung didalam karya arsitektur. Eksistensi semiotika Saussure adalah relasi antara penanda dan petanda berdasarkan konvensi, biasa disebut dengan signifikasi. Semiotika signifikasi adalah sistem tanda yang mempelajari relasi elemen tanda dalam sebuah sistem 
berdasarkan aturan atau konvensi tertentu. Kesepakatan sosial diperlukan untuk dapat memaknai tanda tersebut. Menurut Saussure, tanda terdiri dari: Bunyi-bunyian dan gambar, disebut signifier atau penanda, dan konsep-konsep dari bunyi-bunyian dan gambar, disebut signified.

Straubhaar dan LaRose (2002:14) dikutip oleh Nasrullah dalam buku Teori \& Riset Media Siber mencatat, bahwa adanya perubahan terminology menyangkut media. Perubahan itu berkaitan dengan perkembangan teknologi, cakupan area, produksi masal (mass production), distribusi missal (mass distribution), sampai pada efek yang berbeda dengan apa yang ada di media massa. Adapun menurut John Vivian (2008), keberadaan media baru seperti internet bisa melampaui pola penyebaran pesan media tradisional; sifat internet yang bisa berinteraksi mengaburkan batas geografis, kapasitas interaksi, dan yang terpenting bisa dilakukan secara real time (Nasrullah, 2014: 13-14).

Pada tahun 1990, Mark Poster meluncurkan buku besarnya, The Second Media Age, yang menandai periode baru dimana teknologi interaktif dan komunikasi jaringan, khususnya dunia maya akan mengubah masyarakat. Kekuatan media dalam dan dari media itu sendiri kembali menjadi fokus, termasuk sebuah minat baru dalam karakteristik penyebaran dan penyiaran media (Little John, 2009:413).

\section{METODE PENELITIAN}

Penelitian ini menggunakan metode kualitatif dan strategi penelitian yang digunakan adalah semiotika, dengan tujuan bahwa penelitan ini bertujuan untuk mengkaji makna teks media melalui tanda. Semiotika yang peneliti gunakan adalah semiotika Ferdinand de Saussure yang menekankan penelitian pada tanda berupa linguistik atau bahasa.

Peneliti melakukan observasi pada video Cameo Project yang berjudul Ahok Pasti Kalah yang didapat dari situs berbagi video youtube. Objek penelitian ini adalah akun youtube Cameo Project, serta data yang digunakan merupakan data yang diperoleh dari bahan-bahan bacaan, yaitu literatur, buku, jurnal-jurnal dan lain-lain yang berhubungan dengan penulisan ini mengenai studi semiotika pada video di youtube.

\section{HASIL PENELITIAN}

Nama Cameo Production lebih dikenal Cameo Project di YouTube. Cameo Project mulai dikenal banyak orang setelah mengunggah sebuah music video yang berjudul "JOKOWI DAN BASUKI" - What Makes You Beautiful by One Direction [PARODY] pada masa 
kampanye pemilihan gubernur DKI Jakarta untuk periode tahun 2012-2017. Video tersebut ditonton sebanyak 3.791 .874 kali. Jumlah subscriber Cameo Project makin meningkat semenjak Cameo Project mengunggah karyanya tersebut.

Pada akhir tahun 2016 yang lalu, Cameo Project terpilih sebagai YouTube Creator For Change untuk Indonesia. Dalam arti lain, Cameo Project terpilih sebagai YouTube Ambassador untuk Indonesia karena video-video yang dibuat oleh Cameo Project membicarakan seputar politik dan juga mengangkat masalah sosial yang terjadi di Indonesia. Selain membahas politik dan masalah sosial, Cameo Project juga membuat video lucu tentang kehidupan-kehidupan di Indonesia.

Dari video Cameo Project yang berjudul Ahok Pasti Kalah yang berdurasi 3 menit 16 detik, peneliti menganalisis 42 scene yang didalamnya dibagi menjadi 4 kolom yaitu visual, audio, penanda, petanda. Setiap scene dianalisis pesan yang terlihat atau nampak pada visual video, mulai dari ekspresi aktor sampai teks yang muncul pada video tersebut.

Tabel 4.1 Analisis 1

\begin{tabular}{|c|c|c|c|c|}
\hline No & Visual & Audio & Penanda & Petanda \\
\hline 1. & Martin Anugrah & $\begin{array}{l}\text { "Ahok Pasti } \\
\text { Kalah". }\end{array}$ & $\begin{array}{l}\text { Terdapat teks } \\
\text { "Ahok pasti } \\
\text { KALAH" dengan } \\
\text { font berwarna } \\
\text { merah dan } \\
\text { background putih. }\end{array}$ & $\begin{array}{l}\text { Penekanan pesan pada } \\
\text { awal video, yang } \\
\text { dimana ditunjukan } \\
\text { judul video dengan } \\
\text { intonasi suara yang } \\
\text { tegas, serta dukungan } \\
\text { warna yang mencolok } \\
\text { antara teks dan } \\
\text { background. }\end{array}$ \\
\hline
\end{tabular}

Pada scene 1 visual yang ditampilkan adalah aktor Martin Anugrah dengan latar belakang hitam, serta suara aktor yang didukung text "Ahok Pasti Kalah" berwarna merah. Hitam mempunyai makna kekuatan, kekuasaan, berat, kemewahan, elegan, formal, serius, bergengsi, kesunyian, misteri. Efek pada produk adalah pakaian berwarna hitam membuat seseorang terlihat kurus, warna hitam membuat warna lain terlihat lebih terang, pada terapi psikis, warna hitam memberi efek meningkatkan kepercayaan diri dan kekutatan, diasosiasikan dengan kerahasiaan. (Monica, 2011). Dalam video ini, penggunaan latar belakang hitam memiliki unsur serius agar penyampaian pesan lebih dapat tersampaikan serta 
dukungan warna kontras pada tulisan yang membuat penonton tidak hanya mendengarkan suara tapi juga membaca pesan yang ingin disampaikan oleh Cameo Project.

Tabel 4.2. Analisis 2

\begin{tabular}{|c|c|c|c|c|}
\hline 2. & cting & "Iya itu clickbait" & $\begin{array}{l}\text { Ekspresi raut wajah } \\
\text { santai. }\end{array}$ & $\begin{array}{l}\text { Menjelaskan bahwa } \\
\text { judul "Ahok pasti } \\
\text { kalah" adalah } \\
\text { clickbait. }\end{array}$ \\
\hline 3. & PEMAANONONAN & $\begin{array}{l}\text { "Kalau penduduk } \\
\text { Jakarta gasuka } \\
\text { liat pembangunan } \\
\text { selama } 2 \text { tahun } \\
\text { belakangan". }\end{array}$ & $\begin{array}{l}\text { Muncul tulisan } \\
\text { "pembangunan", } \\
\text { setelah itu muncul } \\
\text { garis merah } \\
\text { mencoret kata } \\
\text { "pembangunan" } \\
\text { tadi. }\end{array}$ & $\begin{array}{l}\text { Martin menyebutkan } \\
\text { bahwa adanya } \\
\text { pembangunan selama } \\
2 \text { tahun terakhir di } \\
\text { Jakarta, yang dimana } \\
\text { Ahok menjadi peran } \\
\text { penting dalam } \\
\text { pembangunan tersebut } \\
\text { yang merupakan } \\
\text { Gubernur Jakarta. } \\
\text { Dengan tulisan } \\
\text { pembangunan dicoret } \\
\text { dengan garis merah, } \\
\text { menandakan bahwa } \\
\text { masyarakat dinilai } \\
\text { tidak setujuan tentang } \\
\text { pembangunan yang } \\
\text { telah dilakukan. }\end{array}$ \\
\hline 4. & $\begin{array}{l}\text { PEJABAT } \\
\text { KOL.UIDSI } \\
\text { SIBANTA: }\end{array}$ & $\begin{array}{l}\text { "Orang-orang } \\
\text { gasuka liat } \\
\text { pegawai } \\
\text { pemerintah dan } \\
\text { pejabat yang } \\
\text { korupsi dibantai } \\
\text { sama Ahok". }\end{array}$ & $\begin{array}{l}\text { Muncul teks } \\
\text { "pejabat korupsi } \\
\text { dibantai" yang } \\
\text { kemudian ditimpa } \\
\text { dengan dua garis } \\
\text { merah. }\end{array}$ & $\begin{array}{l}\text { Pesan yang } \\
\text { ditonjolkan dalam teks } \\
\text { ini yaitu terkait } \\
\text { permasalahan } \\
\text { beberapa pejabat DKI } \\
\text { yang diberhentikan } \\
\text { oleh Ahok. }\end{array}$ \\
\hline
\end{tabular}

Penekanan pada scene 4 adalah tentang Ahok yang memberhentikan Pegawai Negeri Sipil selama menjabat menjadi Gubernur DKI Jakarta. Seperti yang dikutip pada megapolitan.kompas.com, Ahok memaparkan 
"Pecat sudah banyak. Sudah berapa ratus. Hampir tiap hari tanda tangan pemecatan kami. Kalau atasan ketemu enggak masuk 45 hari saja, enggak jelas, kami usulin pecat. Ketahuan terima duit dikit aja dari orang, $R p$ 1,5 juta pun langsung pecat," Kamis (2/6/2016). (Sumber: http://megapolitan.kompas.com/read/2016/06/02/10180411/sejak.ahok.menjabat sebagai.gubernur.sudah.ratusan.pns.yang.dipecat)

Cameo Project menggunakan konsep visual Text berwarna putih ditimpa dengan garis berwarna merah. Putih menggambarkan kejujuran dan merah diartikan ketidaksetujuan. Secara keseluruhan, makna yang terkandung didalamnya adalah tindak kejujuran yang dilakukan Ahok dan dianggap tidak benar oleh orang-orang tertentu yang memungkinkan tidak terpilihnya Ahok menjadi Gubernur DKI Jakarta.

Tabel 4.3 Analisis 3

\begin{tabular}{|c|c|c|c|c|}
\hline 13. & $\begin{array}{l}\text { NGOMONG } \\
\text { HALUS }\end{array}$ & $\begin{array}{l}\text { "Seperti, } \\
\text { ngomongnya } \\
\text { lebih halus. " }\end{array}$ & $\begin{array}{l}\text { Muncul teks } \\
\text { "ngomong halus". } \\
\text { Mengangkat kedua } \\
\text { tangan ke atas. }\end{array}$ & $\begin{array}{l}\text { Berkebalikan dengan } \\
\text { Ahok yang memiliki } \\
\text { kebiasan berbicara } \\
\text { dengan intonasi tinggi, } \\
\text { dan gaya bahasa yang } \\
\text { kurang halus. } \\
\text { Kata ngomong halus } \\
\text { ditujukan kepada } \\
\text { pasangan nomer } 3 \\
\text { yaitu Anies Baswedan } \\
\text { yang memiliki cara } \\
\text { berbicara yang sopan } \\
\text { dan lemah lembut. }\end{array}$ \\
\hline 14. & & $\begin{array}{l}\text { "Muka lebih } \\
\text { ganteng." }\end{array}$ & $\begin{array}{l}\text { Muncul teks "muka } \\
\text { ganteng”. Ekspresi } \\
\text { tersenyum dengan } \\
\text { menggerakan } \\
\text { tangan ke atas. }\end{array}$ & $\begin{array}{l}\text { Kata muka ganteng } \\
\text { ditujukan kepada } \\
\text { pasangan nomer } 3 \\
\text { yaitu Sandiaga Uno. }\end{array}$ \\
\hline
\end{tabular}

Visual yang nampak pada scene 14 adalah teks "muka lebih ganteng". Seperti kutipan Prabowo pada portal berita www.merdeka.com

"Ya kenapa enggak. Seperti Sandiaga Uno belum tentu kalah loh. Dia ganteng, kaya, nggak perlu korupsi lagi kan dia. Sandiaga Uno juga orang yang sudah dikenal masyarakat. Ya dipoles sedikit saja sudah jadi (Gubernur DKI)," ujar Prabowo saat ditemui di gedung DPRD DKI Jakarta, Selasa (22/9). (sumber: 
Ungkapan dari Probowo tersebut sempat viral dan banyak diberitakan pada media massa saat pencalonan Sandiaga Uno untuk menjadi wakil Gubernur Anis Baswedan. Cameo Project mengambil isu tersebut untuk menggambarkan lawan dari pasangan Ahok dan Djarot tersebut. Kampanye pada prinsipnya merupakan suatu proses kegiatan komunikasi individu atau kelompok yang dilakukan secara terlembaga dan bertujuan untuk menciptakan suatu efek atau dampak tertentu. Kampanye sebagai "serangkaian tindakan komunikasi yang terencana dengan tujuan untuk menciptakan efek tertentu pada sejumlah besar khalayak yang dilakukan secara berkelanjutan pada kurun waktu tertentu".

\section{Tabel 4.4 Analisis 4}

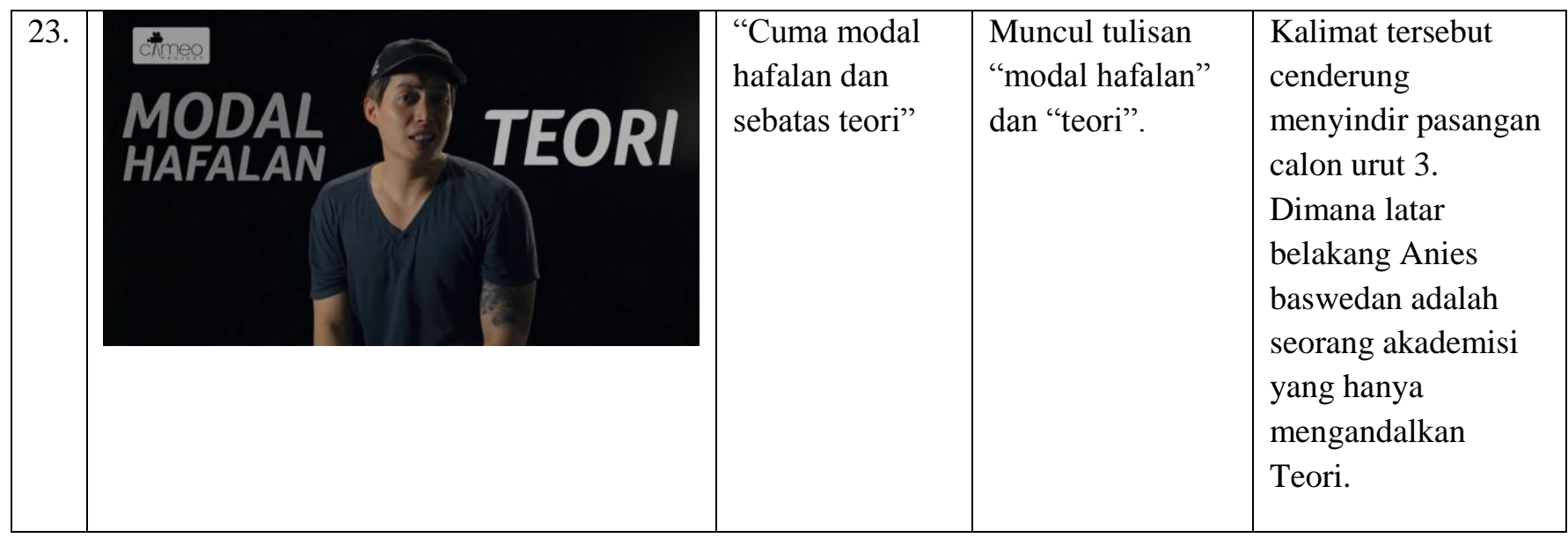

Pada scene 23, muncul tulisan "Cuma modal hafalan dan sebatas teori”. Ahok pernah mengkritisi visi misi calon pasangan nomor 3 yaitu Anis dan Sandiaga uno. Seperti dikutip dalam metronews, Ahok mengatakan

"Kalau kita hanya mengatakan membangun, membangun, manusia, manusia tapi tidak ada bangunan benda matinya. Itu namanya teori saja. Itu ngajar, dosen di kampus. Ingin bangun ini, tapi tidak ada actionnya, (sumber: http://m.metrotvnews.com/pilkada/news-pilkada/5b271Wrk-ahok-kalau-tak-adaactionnya-itu-hanya-teori)

Disimpulkan bahwa adanya ketidakpastian dan ketidakpercayaan terhadap visi misi pasangan nomor urut 3. Penekanan hafalan dan teori menggambarkan sosok Anis yang pernah berprofesi sebagai dosen. 
Tabel 4.5 Analisis 5

\begin{tabular}{|c|c|c|c|c|}
\hline 40. & Aneo & "Ahok Djarot" & $\begin{array}{l}\text { Muncul teks "Ahok } \\
\text { \& Djarot" }\end{array}$ & $\begin{array}{l}\text { Penegasan kalimat } \\
\text { sebelumya agar pesan } \\
\text { yang disampaikan } \\
\text { lebih tersampaikan } \\
\text { oleh penonton }\end{array}$ \\
\hline 41. & 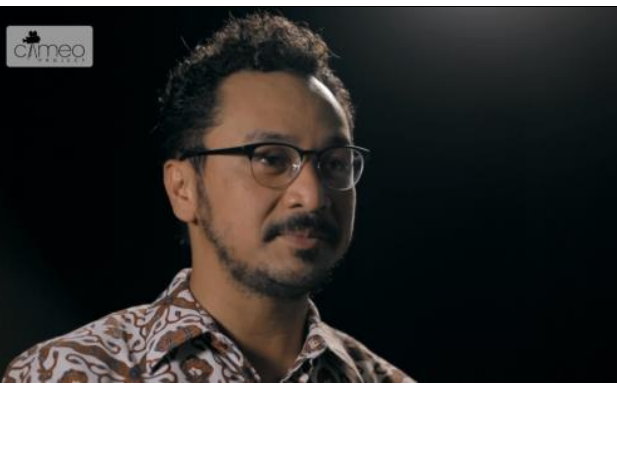 & $\begin{array}{l}\text { "sebagai pelayan } \\
\text { masyarakat DKI } \\
\text { Jakarta" }\end{array}$ & $\begin{array}{l}\text { Pandangan mata } \\
\text { tajam kedepan } \\
\text { dengan mimik } \\
\text { wajah tegas. }\end{array}$ & $\begin{array}{l}\text { Adanya harapan yang } \\
\text { di tujukan kepada } \\
\text { Ahok dan Djarot } \\
\text { untuk menjadi pelayan } \\
\text { masyarakat Jakarta } \\
\text { dan optimisme itu } \\
\text { ditunjukan dengan } \\
\text { pandangan tajam serta } \\
\text { sedikit senyum pada } \\
\text { bibir Giring. }\end{array}$ \\
\hline 42. & 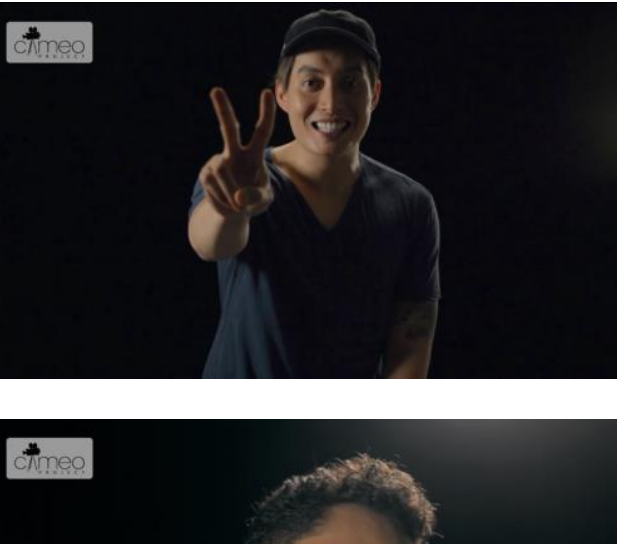 & "Peace" & $\begin{array}{l}\text { Menunjukan } 2 \text { jari } \\
\text { dengan } \\
\text { menonjolkan } \\
\text { ekspresi muka } \\
\text { tersenyum. }\end{array}$ & $\begin{array}{l}2 \text { jari menandakan } \\
\text { nomer urut Ahok pada } \\
\text { pemilihan daerah DKI } \\
\text { Jakarta } 2017 . \\
\text { Ekspresi tersenyum } \\
\text { menandakan bahwa } \\
\text { adanya kepercayaan } \\
\text { diri pada pasangan } \\
\text { Ahok Djarot untuk } \\
\text { memimpin DKI } \\
\text { Jakarta. }\end{array}$ \\
\hline
\end{tabular}

Scene 39 sampai 41 yang mengajak warganet untuk memilih pasangan Ahok dan

Djarot. Penegasan makna memilih Ahok ditunjukan pada scene penutup. Giring, Endric dan Martin mengangkat 2 jarinya yang menandakan nomor urut pasangan Ahok Djarot. Makna lain dari jari telunjuk dan tengah diangkat adalah tanda kedamaian. Itu mencerminkan akan keadilan dan kesejahteraan bagi masyarakat Jakarta. 
Kampanye pada prinsipnya merupakan suatu proses kegiatan komunikasi individu atau kelompok yang dilakukan secara terlembaga dan bertujuan untuk menciptakan suatu efek atau dampak tertentu. Kampanye sebagai "serangkaian tindakan komunikasi yang terencana dengan tujuan untuk menciptakan efek tertentu pada sejumlah besar khalayak yang dilakukan secara berkelanjutan pada kurun waktu tertentu". Cameo Project menggunakan media Youtube untuk menyebar luaskan video kampanye mendukung pasangan Ahok dan Djarot. Dengan data pengguna internet di Indonesia yang mencapai 83,7 juta orang pada tahun 2014 (lembaga riset pasar e-Marketer dikutip oleh tekno.kompas.com). Dari jumlah pengguna internet tersebut 80 persen diantaranya adalah remaja berusia 21-24 tahun (kominfo.go.id). Dengan demografis usia tersebut yang sudah memiliki hak suara untuk memilih, kampanye melalui Youtube sudah bisa dikatakan efektif. Selain penyebaran yang luas, dilihat dari segi ekonomis, Cameo Project tidak membayar untuk penyebaran videonya kepada warganet diseluruh dunia.

\section{DISKUSI}

Menurut Saussure, tanda mempunyai dua entitas, yaitu signifier (signifiant/wahana tanda/penanda/yang mengutarakan/simbol) dan signified (signifie/makna/petanda/yang diutarakan/thought of reference). Tanda menurut Saussure adalah kombinasi dari sebuah konsep dan sebuah sound-image yang tidak dapat dipisahkan. Peneliti menganalisis dengan mengelompokan penanda pada video Ahok Pasti kalah dan petanda yang merupakan makna pada penanda yang muncul.

Ferdinand de Saussure mengatakan penanda merupakan simbol-simbol yang tampak secara visual. Dalam video Ahok Pasti Kalah, peneliti menyimpukan bahwa penanda yang muncul adalah:

1. Aktor sebagai objek utama.

2. Suara perkataan yang dikeluarkan oleh aktor.

3. Gesture tubuh aktor.

4. Latar musik.

5. Latar belakang berwarna hitam.

6. Teks visual.

Makna sebenarnya atau petanda (Signified), peneliti menganalisi melalui tabel dengan mengelompokan visual yang ditampilkan pada video, lalu apa yang dikatakan oleh aktor yang 
ada didalamnya, serta mencari makna apa yang muncul dengan memfokuskan pada makna petanda dan penanda.

Cameo Project menggunakan media Youtube untuk menyebar luaskan video kampanye mendukung pasangan Ahok dan Djarot. Dengan data pengguna internet di Indonesia yang mencapai 83,7 juta orang pada tahun 2014 (lembaga riset pasar e-Marketer dikutip oleh tekno.kompas.com). Dari jumlah pengguna internet tersebut 80 persen diantaranya adalah remaja berusia 21-24 tahun (kominfo.go.id). Dengan demografis usia tersebut yang sudah memiliki hak suara untuk memilih, kampanye melalui Youtube sudah bisa dikatakan efektif. Selain penyebaran yang luas, dilihat dari segi ekonomis, Cameo Project tidak membayar untuk penyebaran videonya kepada warganet diseluruh dunia.

Cameo Project mengemas pesan kampanye yang sangat kompleks. Visual yang ditekankan pada video Ahok Pasti Kalah sangatlah mendukung dengan pesan yang ingin disampaikan. Pengambilan warna pada latar, teks, dan simbol-simbol pendukung seperti garis semuanya menjadi element penting dalam video tersebut. Dalam scene 1, Martin sebagai leader Cameo Project mengemukakan bagaimana kinerja Ahok dalam masa jabatannya menjadi Gubernur Jakarta. Penekanan berulang-ulang jika Ahok adalah gubernur yang memang dibutuhkan masyarakat Jakarta sangatlah terlihat. Adanya kemungkinan Ahok kalah dalam pemilihan gubernur 2017 dikemas dengan menonjolkan kelebihan Ahok dan menjatuhkan lawan pasangan calon lainnya. Ahok dipandang sebagai peran penting dalam pembangunan Jakarta selama 2 tahun terakhir, dengan banyaknya kasus pelaporan pejabat daerah yang korupsi pada masa jabatan Ahok menjadi Gubernur setelah menggantikan Jokowi yang maju sebagai Presiden pada 2014.

Martin mengangkat isu polemik yang melibatkan Ahok mengenai pelaporkan adanya UPS dalam APBD DKI Jakarta yang lebih dikenal sebagai dana siluman. Kepekaan terhadap isu-isu yang muncul sangatlah penting bagi kesuksesan Kampanye yang dibuat menarik agar masyarakat percaya akan kinerja Ahok sebagai Gubernur yang ideal bagi Jakarta. Cameo Project sendiri sebelumnya mendukung pasangan Jokowi-Ahok pada pemilihan Gubernur Jakarta 2012 dengan membuat video parodi "Takotakmiskumis". Ini merupakan dukungan kedua mereka pada Ahok untuk menjadikannya sebagai pemimpin di Jakarta. Scene nomer 2, Martin mengatakan bahwa judul yang ia buat merupakan clickbait yang bertujuan menimbulkan rasa penasaran dan masyarakat yang melihat judul video tersebut langsung ingin membukanya. Terbukti, dalam waktu 2 hari setelah pengunggahannya di media sosial Youtube, video tersebut 
sudah ditonton lebih dari 1 (satu) juta viewers dan menjadi tranding nomer 1. Tapi bukan dengan menghilangkan unsur isi, judul yang diberikanpun mempresentasikan konten dan pesan yang ingin disampaikan. Pengulangan kata-kata "Ahok Pasti Kalah" terlihat pada setiap scene pada video tersebut.

Setiap scene dipertegas dengan tulisan berwarna putih yang berwarna kontras dengan latar belakang setting tempat yang bertujuan untuk mempertegas isi pesan yang disampaikan. Latar belakang hitam memiliki fungsi untuk membuat objek yang ada didepan lebih terlihat dan memfokuskan penontonnya sehingga penonton dapat melihat lebih jelas apa yang sedang dilakukan oleh aktor. Cameo Project mengangkat isu-isu positif terkait Ahok dalam masa jabatannya menjadi Gubernur pengganti Jokowi. Diantaranya, penutupan Kalijodo, tindakan pelaporan yang dilakukan oleh Ahok terkaits pejabat yang terindikasi korupsi, serta kasus perdebatan anggaran DKI Jakarta tentang UPS antara Ahok dan DPRD DKI Jakarta yang menelan anggaran lebih dari satu trliun rupiah.

\section{KESIMPULAN}

Pada tanggal 9 Februari 2017, Cameo Project mengunggah video yang berjudul "Ahok Pasti Kalah!". Video tersebut adalah bentuk kampanye untuk mendukung Basuki Tjahaja Purnama dalam pemilihan umum calon gubernur DKI Jakarta periode 2017 - 2022. Peneliti menganalisis menggunakan Semiotika Ferdinand de Saussure dan menemukan pemaknaan yang terkandung dalam video ini, yaitu:

1. Penggunaan Clickbait pada pemberian judul dengan tujuan menaikan views, tetapi konten yang diberikan tidak terlepas dari judul yang kita gunakan.

2. Adanya sifat mendukung terhadap Ahok dan Djarot yang ditunjukan oleh Cameo Project.

3. Pesan yang terkandung dalam video Ahok Pasti Kalah yaitu pencitraan Ahok sebagai Gubernur yang dibutuhkan oleh masyarakat DKI Jakarta.

4. Pengemasan pesan kampanye yang baik dengan konsep visual teks guna mendukung kalimat yang diucapkan seseorang.

Saran kepada peneliti selanjutnya terkait kampanye menggunakan media sosial dapat lebih luas menganalisis dengan teori-teori retorika dan visual yang berbeda, serta sejauh mana media sosial dapat berpengaruh kepada masyarakat dalam konteks kampanye politik. 


\section{DAFTAR PUSTAKA}

Creswell, John W. 2010. Research Design Pendekaan Kualitatif, Kuantitatif dan Metode Campuran. Yogyakarta: Pustaka Pelajar.

Eco, Umberto. 2009. Teori Semiotika. Yogyakarta: Kreasi Wacana.

Holmes, David. 2012. Teori Komunikasi: Media, Teknologi, dan Masyarakat (Communication Theory: Media, Technology, and Society). Yogyakarta: Pustaka Pelajar.

Kriyantono, Rachmat. 2009. Teknik Praktis Riset Komunikasi. Jakarta: Kencana Prenada Media Group.

Littlejohn, Stephen W \& Karen A. Foss. 2009. Teori Komunikasi, Edisi 9. Yogyakarta. Salemba Humanika.

Moleong, Lexy. 2006. Metodologi Penelitian Kualitatif. Bandung: PT. Remaja Rosdakarya.

Nasrullah, Rulli. 2014. Teori dan Riset Media Siber. Prenada Media Group Kencana.

Nawiroh, Vera. 2014. Semiotika dalam Riset Komunikasi. Bogor: Ghalia Indonesia.

Rakhmat Supriyono. 2010. Desain Komunikasi visual: teori dan aplikasi. Yogyakarta.

Seto, Indiwan. 2013. Semiotika Komunikasi - Aplikasi Praktis bagi Penelitian dan Skripsi Komunikasi Edisi 2. Jakarta: Mitra Wacana Media.

Severin, Werner J. dan James W. Tankard. 2008. Teori komunikasi, Sejarah, Metode, dan Terpaan di Dalam Media Massa. Jakarta. Kencana.

Sobur, Alex. 2013. Semiotika Komunikasi. Bandung: PT. Remaja Rosdakarya.

Sugiyono. 2012. Metode Penelitian Kuantitatif, Kualitatif dan R\&D. Bandung: Alfabet.

Suprapto, Tommy. 2006. Pengantar Teori Komunikasi. Yogyakarta. Media Perssindo.

\section{Jurnal dan Skripsi:}

Ambaran Kusumaningrum. 2015. Youtube stickness (pengaruh Continuance Motivation dan Perilaku berbagi terhadap Youtube Stickness pada Mahasiswa program Studi Ilmu komunikasi S1Reguler Fakultas Ilmu Sosial dan Ilmu Politik Universitas Sebelas Maret Angkatan 2012-2014). Surakarta.

Monica, Laura. 2011. Efek warna dalam dunia desain dan periklanan.Binus University.

Nahrul, Hayat. 2014. Positioning Politik Kampanye Pemilihan Presiden 2014 dalam Iklan Video Musik Youtube. Universitas Hasanudin.

Suyanto. 2004. Aplikasi desain grafis untuk periklanan dilengkapi sampel iklan terbaik kelas dunia. Yogyakarta.

\section{Internet:}

$\underline{\text { www.cameo-tv.com }}$

www.youtube.com/cameoproject

https://www.merdeka.com/politik/prabowo-sebut-sandiaga-uno-ganteng-dan-kaya-bisa-

kalahkan-ahok.html (diakses pada selasa 3 Agustus 2017 14:56)

https://www.youtube.com/intl/id/yt/creators-for-change/creators.html (diakses pada 18

Agustus 2017 20:08)

http://m.metrotvnews.com/pilkada/news-pilkada/5b271Wrk-ahok-kalau-tak-ada-actionnyaitu-hanya-teori (diakses pada 18 Agustus 2017 21:10) 